\title{
Analysis of Structure, Process and Result Indicators in the Family Health Strategy in Mato Grosso: A Comparative Study
}

\author{
Juliane Ferreira Andrade da Fonseca ${ }^{1}$, Márcia Mello Costa De Liberal ${ }^{1}$, Patrícia Siqueira Varela ${ }^{2} \&$ Paola Zucchi $^{1}$ \\ ${ }^{1}$ Federal University of São Paulo (Unifesp), São Paulo, Brazil \\ ${ }^{2}$ University of São Paulo (USP), São Paulo, Brazil \\ Correspondence: Márcia Mello Costa De Liberal, Botucatu Street, Number $740-3^{\text {rd }}$ floor - Room 307, Vila \\ Clementino, Zip Code: 04023-900, São Paulo, Brazil.
}

Received: October 21, 2021

doi:10.11114/ijsss.v9i6.5383
Accepted: November 15, $2021 \quad$ Available online: November 22, 2021

URL: https://doi.org/10.11114/ijsss.v9i6.5383

\begin{abstract}
This research aimed to correlate the indicators of Primary Health Care in their structural components with those of the process and with the results in the municipalities of Mato Grosso, Brazil, from 2008 to 2015. This is an evaluative, quantitative, retrospective research with the use of secondary data from information systems. A matrix is composed of components of the structure (potential population coverage) the process (medical consultation, home visit of doctor and nurse, referral to the specialist, and request of clinical pathology exams), and the result (hospitalization rate due to sensitive causes). It was constructed when primary care, the proportion of live births of mothers with seven or more prenatal consultations, and the infant mortality coefficient) and the descriptive analysis and Spearman correlation coefficient (rho) were performed. The study found that population coverage remained high above $83 \%$ and the process indicators suggest an improvement in family health strategy, with a reduction of $63.13 \%$ in the average referral to a specialist and $49.71 \%$ in the request for clinical pathology exams. However, there was a $7.13 \%$ reduction in the average home visit during the study period. There is a correlation between the structure and process component and between structure and result. It has been found that with the evolution of the Family Health Strategy, there were changes in some indicators of primary care, but it is not possible to state that there was a change in the care model.
\end{abstract}

Keywords: family health strategy, primary health indicators, health management

\section{Introduction}

The Family Health Strategy (FHS), known as the Family Health Program, was adopt by the Ministry of Health (MH) in 1997 as an innovative model of health care in order to transform the conventional care model, centered on healing and in disease, hitherto prevalent in the Brazilian health system (Vasconcelos, Bosi, \& Pontes, 2008). It has its roots in primary health care and as a strategy to change the care model and it uses specific technologies for the development of its work. In addition to expand coverage and access to health services, the program had the task of replacing the conventional mode of action with new care practices. They have based on the integrality of actions focused on the individual, the family and the community, guided by the principles of surveillance health, health promotion, protection and recovery, causing reflexes at all levels of the system (Teixeira \& Solla, 2008; Binda, Bianco, \& Sousa, 2013).

The National Policy for Primary Care (NPPC) recommends that primary health care (AB), through the FHS, be the first contact of users and coordinator of their care in the service network. The family health teams must organize the practices in the Family Health Units (FHU), showing the multidisciplinary and interdisciplinary character, with the provision of comprehensive, continuous, quality care, also taking responsibility for referrals to specialists and their follow-up for total health recovery, at home, at school and in community centers. With these changes in care practices and the organization of primary care, the FHS would be able to solve $85 \%$ of the health cases in its area of activity (Brasil, 1997). The evaluation of primary care has been growing since the late 1990s, within the scope of the Primary Care Department of the Ministry of Health in order to contribute to the qualification of health care. Therefore, the FHS has been an inducer of this evaluation process with the challenge of conducting research that points to evidence about the different dimensions of the innovations proposed by the strategy in the organization of the system and in the population's health (Furtado \& Vieira-da-Silva, 2014). 
Donabedian (1990) proposes an evaluation of the quality of health care through a matrix composed of components of structure, process and result called the guiding triad of the evaluation of services, systems or programs. This model assumes that good structural conditions are favorable preconditions for a good process, which increases the likelihood of positive outcomes. The municipalities of Mato Grosso (MT) joined the FHS from 2008 and it is expected that changes have occurred in the model of assistance to primary care and, consequently, in the indicators of structure, process and results. Therefore, this study aims to compare the indicators of structure, processes and results of primary care in the municipalities of Mato Grosso for the years 2008 and 2015, more specifically those related to the FHS.

\section{Method}

It is an evaluative, retrospective and quantitative research using the secondary data obtained by the information systems related to the Family Health Strategy, namely: Primary Care Information System (PCIS), HUS Hospital Information System (HIS-HUS), Live Birth Information System (LBIS), Mortality Information System (MIS) and Local Information System of the State Health Department of Mato Grosso. The population of the study was form by all municipalities in this state, consisting of 141 municipalities. The period studied refers to the year of 2008, when all municipalities had already joined the FHS in MT and that the information was registered in all information systems. The year of 2015 was chosen because of the possibility of modifying the assistance model since the municipalities joined the ESF and because it was the last year of all the information contained in the information systems that were needed could be obtained.

The operationalization of the indicators has based on the principles of the FHS, which should have an expression in practice, articulated around two major blocks: access and integrality. To define the Primary Health Care indicators, Ordinances GM 399/2006 and 325/2008, manuals and technical standards of the Ministry of Health, which establish priorities, objectives, goals and indicators of the Pact for Life were consider. The indicators that are part of the priority of the Pact for Life were select: "strengthening primary care", being adapted to the work of Donabedian (1990) regarding the components of Structure, Process and Result that were available in information systems of the Ministry of Health.

The table 1 presents the structure, process and result components with the primary health care indicators, according to the Pact for Life adapted to the work of Donabedian (1990).

Table 1. Components of structure, process and result with the Primary Health Care indicators, according to the Pact for Life

\begin{tabular}{|c|c|}
\hline COMPONENTS & INDICATORS USED \\
\hline $\begin{array}{l}\text { Structure - are the resources (material, human, } \\
\text { financial and technical) previously available to carry out } \\
\text { the activities of an intervention (project, program or } \\
\text { service). }\end{array}$ & $\checkmark \quad$ Potencial population coverage \\
\hline $\begin{array}{l}\text { Process - is the set of activities during which and by } \\
\text { which resources are mobilized and used by the actors to } \\
\text { produce goods and services required to meet the } \\
\text { purposes of the organized system of action. }\end{array}$ & $\begin{array}{ll}\checkmark & \text { Average medical consultation per year } \\
\checkmark & \text { Home visit per family per year } \\
\checkmark & \text { Referral to specialist per year } \\
\checkmark & \text { Request for clinical pathology exams per year }\end{array}$ \\
\hline $\begin{array}{l}\text { Result - these are the intermediate effects of the } \\
\text { intervention, observed, in general, in the target } \\
\text { population. }\end{array}$ & $\begin{array}{ll}\checkmark & \text { Hospitalization rate for conditions sensitive to primary care } \\
\checkmark & \text { Proportion of live births to mothers with seven or more prenatal } \\
\text { visits } \\
\checkmark & \text { Infant Mortality Coefficient }\end{array}$ \\
\hline
\end{tabular}

For the calculation of each indicator, the proposal was use in Ordinances GM 399/2006 and 325/2008 and in the Notebook of Guidelines, Objectives, Goals and Indicators - 2013/2015, being the same calculations that the municipalities must adopt to monitor the indicators agreed. For a better understanding of the data source and the selected indicators, Table 2 has prepared below. 
Table 2. Component, source, data and indicator identification for the proposed study

\begin{tabular}{|c|c|c|c|c|}
\hline Component & Data Source & Data & Indicator & Unit of Measure \\
\hline \multirow[b]{2}{*}{ Structure } & PCIS & $\begin{array}{c}\text { Total population } \\
\text { registered in the FHS }\end{array}$ & \multirow[b]{2}{*}{ Population Coverage } & \multirow[b]{2}{*}{$\begin{array}{l}\% \text { of the population } \\
\text { covered by the FHS }\end{array}$} \\
\hline & IBGE & $\begin{array}{c}\text { Estimated resident } \\
\text { population by } \\
\text { municipality }\end{array}$ & & \\
\hline \multirow{5}{*}{ Process } & PCIS & $\begin{array}{c}\text { Number of medical } \\
\text { appointments per year }\end{array}$ & \multirow[b]{2}{*}{ Medical appointment } & \multirow{2}{*}{$\begin{array}{c}\text { Average medical } \\
\text { visits/residents/year }\end{array}$} \\
\hline & IBGE & $\begin{array}{c}\text { Estimated resident } \\
\text { population by } \\
\text { municipality }\end{array}$ & & \\
\hline & PSIS & $\begin{array}{l}\text { Number of home visits } \\
\text { by the doctor and nurse } \\
\text { per year }\end{array}$ & \multirow{3}{*}{ Home visit } & \multirow{3}{*}{$\begin{array}{l}\text { Number of Home } \\
\text { Visits/family/year }\end{array}$} \\
\hline & PCIS & $\begin{array}{c}\text { Number of families per } \\
\text { year }\end{array}$ & & \\
\hline & IBGE & $\begin{array}{c}\text { Average people per } \\
\text { family } \\
\end{array}$ & & \\
\hline \multirow{3}{*}{ Process } & PCIS & $\begin{array}{l}\text { Number of referrals to } \\
\text { specialist per year } \\
\text { Number of medical } \\
\text { appointments per year }\end{array}$ & Referral to specialist & $\begin{array}{l}\text { Referral number to } \\
\text { specialist /Medical } \\
\text { appointments/year }\end{array}$ \\
\hline & PCIS & $\begin{array}{l}\text { Number of requests for } \\
\text { clinical pathology exams } \\
\text { per year }\end{array}$ & \multirow{2}{*}{$\begin{array}{l}\text { Request for Clinical } \\
\text { Pathology Exams }\end{array}$} & \multirow{2}{*}{$\begin{array}{l}\text { Clinical pathology exam } \\
\text { request number/ Medical } \\
\text { appointments /year }\end{array}$} \\
\hline & PCIS & $\begin{array}{l}\text { Number of medical } \\
\text { appointments per year }\end{array}$ & & \\
\hline & HIS-HUS & $\begin{array}{c}\text { Number of } \\
\text { hospitalizations for } \\
\text { pathology - list of ICD } \\
10 \text { morbidities: asthma, } \\
\text { pneumonia, heart failure } \\
\text { and gastroenteritis } \\
\text { diarrhea by place of } \\
\text { residence }\end{array}$ & \multirow[t]{2}{*}{$\begin{array}{l}\text { Hospitalization rate for } \\
\text { causes sensitive to } \\
\text { primary care }\end{array}$} & \multirow[t]{2}{*}{$\%$ of hospitalization/ year } \\
\hline & IBGE & $\begin{array}{c}\text { Estimated resident } \\
\text { population by } \\
\text { municipality }\end{array}$ & & \\
\hline & LBMSP & $\begin{array}{l}\text { Number of live births to } \\
\text { mothers living in the } \\
\text { municipality with seven } \\
\text { or more prenatal } \\
\text { consultations. } \\
\text { Total live births of } \\
\text { mothers living in the } \\
\text { municipality in the same } \\
\text { period }\end{array}$ & $\begin{array}{l}\text { Proportion of live births } \\
\text { to mothers living in the } \\
\text { municipality with seven } \\
\text { or more prenatal } \\
\text { consultations }\end{array}$ & $\%$ Live births/year \\
\hline & MIS & $\begin{array}{l}\text { Number of deaths of } \\
\text { residents under one year } \\
\text { of age in the year }\end{array}$ & \multirow{2}{*}{$\begin{array}{l}\text { Infant Mortality } \\
\text { Coefficient }\end{array}$} & \multirow{2}{*}{$\begin{array}{c}\text { Number of deaths/ } 1000 \\
\text { live births/year }\end{array}$} \\
\hline & LBMSP & $\begin{array}{c}\text { Total live births of } \\
\text { mothers living in the } \\
\text { same period }\end{array}$ & & \\
\hline
\end{tabular}

Discription: PCIS - Primary Care Information System

The data has exported and organized in Excel 2010 for Windows spreadsheets for adequate storage of information. Statistical analyzes were performed using the Statistical Package for the Social Sciences (SPSS) for Windows, version 20.0. The statistical analysis of all the information collected in this research was do initially in a descriptive way 
through the mean, median, minimum and maximum values, standard deviation and absolute and percentage frequency. The study was approved by the Research Ethics Committee of Unifesp/EPM under number 691.439.

\section{Results}

In a total, 141 municipalities in Mato Grosso, 106 (75.2\%) presented complete information, allowing the analysis of the selected indicators. When analyzing the size of the municipalities, 98 (92.5\%) are small (up to 50,000 inhabitants), 5 (4.7\%) medium-sized (up to 500,000 inhabitants) and 3 (2.8\%) of large size (more than 500,001 inhabitants).

Table 3 presents the primary care indicators according to the structure, process and result components for the years of 2008 and 2015. Mato Grosso had a population of 2,373,858 inhabitants in 2008, increasing in 2015 to 2,642,641, with a growth population of $11.32 \%$. The average population coverage (CP) of the Family Health Strategy in 2008 was $83.33 \%$, and $87.69 \%$ in 2015 , with a percentage increase of $5.23 \%$ in the period.

The average medical consultation (CM) was 1.19 medical consultations/resident /year in 2008, increasing to 1.55 in 2015. Regarding home visits, some municipalities had a minimum value lower than a home visit / family/year. The average home visit was 23 home visits/family/year in 2008, declining to 21.36 in 2015. With regard to Referral to specialist, the average ranged from 0.19 referral to specialist/medical consultation/year in 2008 to 0.07 in 2015 .

Regarding the Request for clinical pathology exams, the average was 1.73 requests for clinical pathology exams/medical consultation/year in 2008, reducing to 0.87 in 2015. With regard to the Hospitalization Rate for Causes Sensitive to Primary care (HRCSPC), the average decreased in the period studied, with $35.61 \%$ in 2008 and $28.81 \%$ in 2015. Regarding the proportion of Live Births of Mothers with Seven or more prenatal Consultations, it has also observed that the maximum value of this indicator remained high during the period in 2008 it was $95.37 \%$, increasing to $96.90 \%$ in 2015. Regarding the Infant Mortality Coefficient (IMC), the average decreased in 2008 it was 20.30/thousand live births and in 2015, it was 13.91 .

Table 3. Behavior of primary care indicators according to the components of structure, process and result in the period from 2008 to 2015

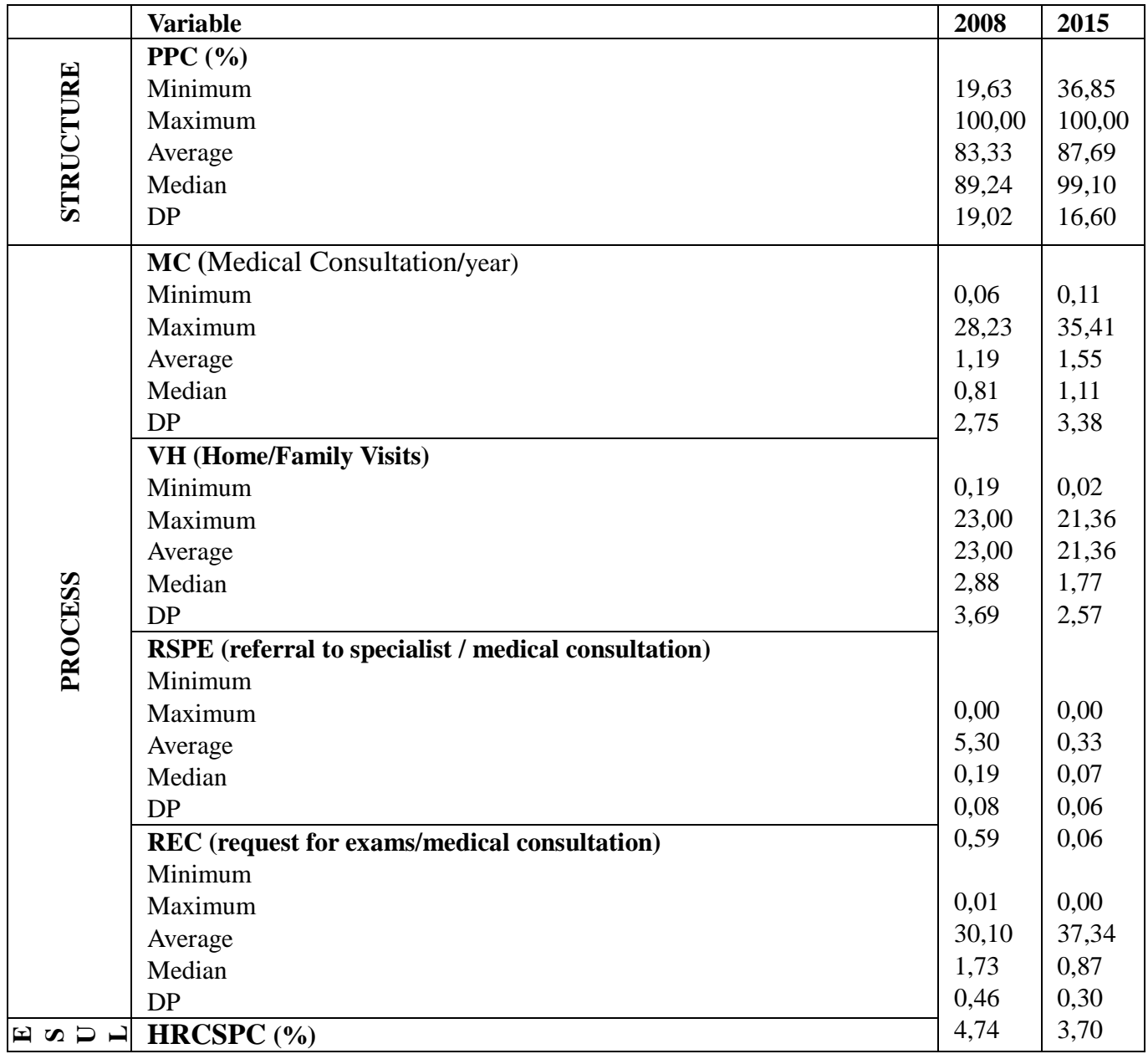




\begin{tabular}{|l|l|l|l|}
\hline Minimum & 0,00 & 5,75 \\
Maximum & 79,74 & 73,33 \\
Average & 35,61 & 28,81 \\
Median & 33,48 & 28,27 \\
DP & 13,67 & 12,25 \\
\cline { 2 - 2 } & & \\
Minimum & 20,00 & 24,00 \\
Maximum & 95,37 & 96,90 \\
Average & 63,09 & 70,88 \\
Median & 63,83 & 71,96 \\
DP & 19,19 & 12,86 \\
\cline { 2 - 3 } & IMC (per thousand NV) & & \\
Minimum & 0,00 & 0,00 \\
Maximum & 100,00 & 111,11 \\
Average & 20,31 & 13,91 \\
Median & 15,15 & 11,67 \\
DP & 20,49 & 14,66 \\
\hline
\end{tabular}

Discription: PPC - Potential Population Coverage, MC - Medical Consultation, VH - Visit - Home, RSPE - Referral to Specialist, REP - Request for Examination Pathology - Clinic, HRCSPC - Hospitalization Rate for Causes Sensitive to Primary Care, LBM7C - Live Births of Mothers with more than 7 prenatal Consultations, IMC - Infant Mortality Coefficient.

\section{Discussion}

After The results of the study contribute to the FHS evaluative research, especially the effectiveness of the program in primary care indicators. The positivity of the potential population coverage, referral to specialist, request for clinical pathology exams and the result indicators (Hospitalization rate for conditions sensitive to primary care, Proportion of live births to mothers with seven or more prenatal consultations and Coefficient Infant Mortality) are strong factors for the maintenance and expansion of the FHS in Mato Grosso.

The state has a large territorial extension, but has a low population density, 3.36 inhabitants $/ \mathrm{km} 2$, according to the 2010 population census (IBGE, 2012). The state has 141 municipalities and the vast majority $(92.9 \%)$ has less than 50 thousand inhabitants. Some authors point out that small municipalities have difficulties in implementing the FHS due to low technical qualifications in management, high turnover of health professionals, professionals with little specific training associated with little training time and inexistence of permanent education, difficulties in accessing health services. medium and high complexity technologies, which ends up requiring alternatives in the management of HUS to meet the needs at all levels of care (Silva, 2011; Botti et al., 2013).

The results of the behavior of the primary care indicators in the FHS in this study presented that was found that the proportion of population coverage by the family health team was high, above $80 \%$ at the over the eight years studied regarding the structure component. Thus corroborating the results obtained in studies (Silva, 2011; Malta, Santos, Stopa, Vieira, Melo, \& Reis, 2016), which showed an increase in population coverage above $80 \%$ in the states of Tocantins, Paraíba and Piauí, in rural areas and in a small municipality of Brazilian territory.

With the increase in the population coverage of the FHS, is supposed to be expect to increase the population's access to health services because, according to the MS, this is the gateway to health services, incorporating improvements in the care received. It reflects in the health indicators as reduction in mortality childhood, early detection of cancers, lower mortality due to preventable causes and increased life expectancy (Binda, Bianco, \& Sousa, 2013; Malta, Santos, Stopa, Vieira, Melo, \& Reis, 2016).

With the increase in demand from family health teams, changes in care practices have expected to occur, guaranteeing the overcoming of the health and life needs of the enrolled population. The FHS emerged as a new care model and reorganization in the work process, with a multidisciplinary team, with the family as the center of attention, moving away from individualized and disease-centered care. To this end, the strategy has based on activities that focus on disease prevention and health promotion, with a resolution of more than $85 \%$ of the needs of the enrolled population.

In this premise, when analyzing the data of this work, considering the process component as activities that involve the multidisciplinary team, we sought to explore the indicators in order to find breaks with the care model centered on the disease. The indicators medical consultations, home visits, referrals to specialists considering the organization of the referral and counter-referral system and the request for clinical pathology tests, these activities, with the implementation 
and evolution of the FHS, suggest an improvement in the FHS in the municipality (Brasil, 2010).

Therefore, there are some differences in the behavior of the process indicators. It has observed that there was an increase $(+30.25 \%)$ in the average of medical consultations in the years studied 2008 and 2015, suggesting that there was an improvement in access to the primary care service. On the other hand, the average number of home visits per family per year made by the doctor and nurse has declined over time (-7.13\%), leaving something to be desired as an essential tool in family health. On the other hand, the average number of referrals to specialists, which had a significant reduction between 2008 and $2015(-63.16 \%)$, which can make us think that the FHS is managing to solve health problems in primary care. The same phenomenon occurred with the request for clinical pathology tests with a reduction $(-49.71 \%)$ in the analyzed period.

The medical consultation at the FHS has specific characteristics: it seeks to increase, strengthen the "patient and professional" bond, focused on understanding the individual's needs, and not just the disease, with participation and negotiation with the person being cared for, carrying out an approach comprehensive approach to the management of the disease and its family (Ramos, 2008). The average number of medical consultations in Mato Grosso seems to point to an inadequate performance of the Family Health team when compared to the parameters stipulated through Ordinance 1101/2002, which estimates three consultations/inhabitant/year (Lima et al., 2016). Although the average medical consultation is below, other factors may be contributing, such as the difficulty in accessing the service in rural units and other activities that are required such as home visits and health education. Corroborates with our study, the research by Lima et al. (2016) also had an average medical consultation below the parameters stipulated by the Ministry of Health in poorer municipalities and rural units.

The results pointed out in our research leads us to reflect that if the increase in population coverage, the FHS increased the population's demand for medical care, however this demand is preventing the multi professional team from carrying out other planned extra-consulting activities that cause changes in care practices of the registered community and manage to solve health problems. The study by Viegas, Carmo and Da Luz (2015) corroborates this perception, which points out as a negative impact on the relationship between family health professionals and users, the long time between scheduling and medical consultation and the high demand of people wanting to schedule a medical appointment.

One of the planned extra-office activities is the home visit, which has different characteristics, was consider a working tool of the multi professional team that enables the approximation with the family, understanding how the relationships between the people that constitute it occur, points out the weaknesses in self-care, diagnoses of community health issues and promotes health education (Ferreira et al., 2017). In addition to welcoming, early diagnosis and treatment at the level of primary health care, the FHS must to be organize in a way that allows the integrality of the individual's health care with the other health services. The FHS becomes a power in the regulatory action of the municipal health care network, as it is what will direct the user to the specialist. The network must to be organize, and must have clear and widely known standards and mechanisms for referral and counter-referral flows by ESF professionals so that there are no "holes" when transferring a patient to a specialized service. If this system is not organized, it ends up compromising the effectiveness of the strategy (Araujo \& Rocha, 2018).

According to our results, the average number of referrals to specialists has reduced significantly. Similar to our result, the study by Cruz et al. (2013) with FHS doctors in 14 municipalities in Minas Gerais, in 2012, pointed out that 93.5\% of the participants stated that they had reduced referrals to specialists after the implementation of the FHS. In the study by Ferreira et al. (2017) with the FHS professionals, the participants reported uncertainties and insecurities in the operationalization of the municipal regulation system, emphasizing the importance of professionals in acquiring new skills for the performance of their functions in this new work proposal. Perhaps it may be that these same feelings are present in the professionals of the family health teams in Mato Grosso. Despite the advance of the FHS in certain locations, as the researchers point out, the reality that is observed in the daily lives of health units are "loose and lost" patients with referral to a specialist in their hands, but without knowing who to turn to, which ends up compromising the integral monitoring of their health.

Regarding the request for clinical pathology exams per medical consultation per year to assist in medical diagnosis and treatment follow-up, in Brazil, there are few studies that directly address the request for medical exams, being fragmented and not consistent with the reality of the medical system health as a whole. The reflection of this process component leads us to recognize that, in order for there to be a change in the homogeneous health model, it is necessary that there be changes in the behavior of all those involved, going through managers, health professionals and reaching users. For this to happen, it is necessary to modify the training of health professionals who will be working in the FHS in the future.

The training of health professionals must have based on two pillars: inter/transdisciplinarity in teamwork and interaction/communication between the team and the community. The interdisciplinary work has as meaning "the 
possibility of the practice of a professional being reconstructed in the practice of the other, transforming both in the intervention of the context where they are inserted". Communication between the team, on the other hand, is the ability to speak and listen to the other seeking agreements for mutual understanding, in this process imposition, coercion and extortion are excluded (Cruz, 2013). As for the result component, this study chose three indicators that have related to access, morbidity and mortality which were influence by the presence of primary health care potentially.

The results presented in this research describe a positive behavior of these indicators, pointing to a decline in the hospitalization rate for causes sensitive to primary care, an increase in the proportion of live births to mothers with seven or more prenatal consultations and a reduction in the infant mortality rate. In our results, comparing the maximum value of HRCSPC in 2008 (79.74\%) and the maximum value in 2015 (73.33\%), there was a reduction of $8.04 \%$ in hospitalizations. The average in 2008 was 35.61 and, in 2015, was 28.81. The FHS may have contributed to the reduction of this indicator.

This study has limitations as it considers only secondary data from official MS information systems and, in this sense, subject to possible biases related to the quality of the available data. However, there is an improvement in the quality of information and the great availability of this information, which may also have contributed to the increase in values at certain times. In addition, when analyzing this indicator, it is also necessary to consider the living conditions of the population studied as a socio-demographic and economic profile of the populations, including the specific epidemiological situations, the organization of the existing service network and the activities of the FHS teams in particular.

A similar study using secondary data, carried out by Moura et al. (2010) with data from the Hospital Information System from 1999 to 2006, analyzing the trends of the main causes of hospitalizations sensitive to primary care, demonstrated the reduction in hospitalization rates for gastroenteritis $(-12.0 \%)$ and asthma $(-31,8 \%)$ and $142.5 \%$ increase in hospitalization rates for bacterial pneumonia. Another study analyzing HRCSPC in children under 5 years old and its relationship with the proportional expansion of the FHS in the period from 2000 to 2010 in Piauí, showed positivity in the general proportion of the hospitalization rate, mainly a significant decline in infectious and parasitic diseases (Barreto, Nery, \& Costa, 2012).

In a study by Santos et al. (2017) with FHS doctors in Minas Gerais, with the objective of knowing the doctors' perception of the indicator hospitalization for sensitive causes in primary care, there was a lack of knowledge of this indicator and the non-use of it in the planning of actions intervention, prevention and health promotion. Another indicator used to analyze the quality of maternal and child health care in the scope of primary care refers to prenatal care, following the criteria of the Humanization of Childbirth and Birth Program implemented by the Ministry of Health in 2000. It aims to increase and to improve access and early care for pregnant women, ensuring a minimum of six prenatal consultations, and a series of other actions to reduce maternal and child morbidity and mortality (Oyerinde, 2013; Lansky et al., 2014; Tomasi et al., 2017).

In this study, the proportion of live births to mothers with seven or more prenatal consultations was assess. It is important to notice that this indicator has maximum values above $90 \%$ in the years studied, with a $1.6 \%$ increase between the years 2008 and 2015. These data are satisfactory which may infer that pregnants women have access and are been monitored by professionals of family health. The average was $63.09 \%$ and $70.88 \%$ respectively in 2008 and 2015. It signals positivity, but that there is still a need for improvement. Other studies pointed to results on this indicator such as which that is part of the external evaluation of the first cycle of the National Program for the Improvement of Quality and Access to Primary Care. They carried out in all family health units in Brazil, pointing out that of the 227 women interviewed, $89 \%$ answered that they had more than six prenatal consultations (Corrêa, Tsunechiro, Lima, \& Bonadio, 2014).

The same phenomenon of positivity could be verified when analyzing the Infant Mortality Coefficient in the studied period, which presented a decline of $31.51 \%$. In Brazil, during 2011, the infant mortality rate was 15.3 per thousand live births, reaching goal 4 of the Millennium Development Goals, a commitment by United Nations governments to improve child health and reduce by 2/3 infant mortality between 1990 and 2015 (Maranhão et al., 2012); Murray, Laakso, Shibuya, Hill, \& Lopez, 2015). Similar to our result, the study by Carneiro et al. (2016), in the city Marajó, region of Pará, was observed a decreasing trend in the infant mortality rate in children under five years after the implementation of the family health strategy.

A study carried out from 2010 to 2014 in the Legal Amazon region showed a reduction in the infant mortality rate in municipalities with more than one year of implementation of the FHS (Kafer, 2016). Malta et al. (2016) state that prevention activities such as immunization, assistance to women during prenatal and childbirth and monitoring children in the first years of life, are strategies that collaborate to reduce the majority of infant deaths in Brazil. 


\section{Conclusion}

Even without the use of a more in-depth statistical methodology, the research allowed us to verify that, with the evolution of the FHS, there were changes in some primary health care indicators in 2015 compared to 2018. The results point to a timid change in the behavior of the process' component, however it is not possible to say that there was a change in the assistance model.

Regarding the result component, it showed better behavior, suggestive of changes in the individuals' health conditions. The type of analysis carried out in the study contributes may represent a management tool regarding the analysis of the indicators related to the FHS, allowing management feedback for health professionals and allowing discussions and reflections for planning interventions aimed at improving the population's health adscript.

\section{Acknowledgements}

This study was funded by CAPES. It is a partial product of a doctorate research developed at the Federal University of São Paulo and approved by the Research Ethics Committee of the University.

\section{References}

Araujo, M. B. de S., \& Rocha, P. de M. (2007). Trabalho em equipe: um desafio para a consolidação da estratégia de saúde da família. Washington, DC: American Psychological Association. https://doi.org/10.1590/S1413-81232007000200022

Barreto, J. O. M., Nery, I. S., \& Costa, M. do S. C. (2012). Estratégia Saúde da Família e internações hospitalares em menores de 5 anos no Piaú, Brasil. Cad. Saúde. Pública, 28(3), 515-526. https://doi.org/10.1590/S0102-311X2012000300012

Binda, J., Bianco, M. D. F., \& Sousa, E. M. D. (2013). O trabalho dos agentes comunitários de saúde em evidência: uma análise com foco na atividade. Saúde e Sociedade, 22, 389-402. https://doi.org/10.1590/S0104-12902013000200011

Botti, C., Artmann, E., Spinelli, M. A. S., \& Scatena, J. H. G., et al. (2013). Regionalização dos Serviços de Saúde em Mato Grosso: um estudo de caso da implantação do Consórcio Intermunicipal de Saúde da Região do Teles Pires, no período de 2000 a 2008. Epidemiologia e Serviços de Saúde, 22(3), 491-500. https://doi.org/10.5123/S1679-49742013000300014

Brasil, Ministério da Saúde (2010). Memórias da saúde da família no Brasil. Secretaria de Atenção à Saúde. Departamento de Atenção Básica. Brasília.

Brasil, Ministério da Saúde. (1997). Saúde da Família: uma estratégia para reorganização do modelo assistencial. Manual Técnico. Brasília.

Carneiro, V. B., Oliveira, P. T. R., Bastos, M. S. C. B., \& Alvarenga, E. C. (2016). Avaliação da Mortalidade e Internações por condição sensível à Atenção Primária em menores de 5 anos, antes e durante o Programa Mais Médicos, no Marajó-Pará-Brasil. Saúde em Redes, 2(4), 360-371. https://doi.org/10.18310/2446-4813.2016v2n4p360-371

Corrêa, M., Tsunechiro, M., Lima, M., \& Bonadio, I. (2014). Evaluation of prenatal care in unit with family health strategy. Revista da Escola de Enfermagem da USP, 48(spe), 23-31. https://doi.org/10.1590/S0080-623420140000600004

Cruz, C. S. S. (2013). Avaliação do Programa de Educação Permanente para médicos da Estratégia de Saúde da Família na região ampliada de saúde Jequitinhonha de Minas Gerais. Federal University of Vales do Jequitinhonha e Mucuri. Theses.

Cunha, M. S. D., \& Sá, M. D. C. (2013). A visita domiciliar na estratégia de saúde da família: os desafios de se mover no território. Interface-Comunicação, Saúde, Educação, 17, 61-73. https://doi.org/10.1590/S1414-32832013000100006

Donabedian, A. (1990). Garantía y monitoria de la calidad de la atención médica: um estúdio introductorio. Instituto Nacional de Salud Publica. México.

Ferreira, J., Caldas, D. C., Santos, L. L. dos, Ribeiro, L. C., \& Chaves, L. D. P. et al. (2017). Aspectos da regulação em saúde na visão de equipes de saúde da família de um município de pequeno porte. Revista Brasileira de Medicina de Família e Comunidade, 11(38), 1. https://doi.org/10.5712/rbmfc11(38)1188

Furtado, J. P., \& Vieira-da-Silva, L. M. (2014). A avaliação de programas e serviços de saúde no Brasil enquanto espaço de saberes e práticas. Cadernos de Saúde Pública, 30, 2643-2655. https://doi.org/10.1590/0102-311x00187113

Instituto Brasileiro de Geografia e Estatística (IBGE). (2012). Censo Brasileiro de 2010. Rio de Janeiro. Retreived from 
https://censo2010.ibge.gov.br/resultados.html

Kafer, M. C. (2016). Avaliação dos efeitos da implantação do Programa Equipe de Saúde da Família Ribeirinha na Amazônia Legal. Brasília University. Theses.

Lansky, S., Friche, A. A. de L., Silva, A. A. M. da, Campos, D., Bittencourt, S. D. de A., \& Carvalho, M. L., et al. (2014). Pesquisa Nascer no Brasil: perfil da mortalidade neonatal e avaliação da assistência à gestante e ao recém-nascido. Cad. Saúde Pública, 30(1), S192-S207. https://doi.org/10.1590/0102-311X00133213

Lima, R. T. S., Fernandes, T. G., Baleiro, A. A. S., Costa, F. S., Schramm, J. M. A., Schweickardt, J. C., \& Ferla, A. A. (2016). A Atenção Básica no Brasil e o Programa Mais Médicos: uma análise de indicadores de produção. Ciência \& Saúde Coletiva, 21(9), 2685-2696. https://doi.org/10.1590/1413-81232015219.15412016

Malta, D., Santos, M., Stopa, S., Vieira, J., Melo, E., \& Reis, A. (2013). A Cobertura da Estratégia de Saúde da Família (ESF) no Brasil, segundo a Pesquisa Nacional de Saúde. Ciência \& Saúde Coletiva, 21(2), 327-338. https://doi.org/10.1590/1413-81232015212.23602015

Maranhão, A. G. K., Vasconcelos, A. M. N., Porto, D. L., \& França, E. et al. (2012). Mortalidade infantil no Brasil: tendências, componentes e causas de morte no período de 2000 a 2010. Saúde Brasil 2011: uma análise da situação de saúde e a vigilância da saúde da mulher, 1, 163-82.

Moura, B. L. A., Cunha, R. C. da, Aquino, R., Medina, M. G., Mota, E. L. A., Macinko, J., et al. (2010). Principais causas de internação por condições sensíveis à atenção primária no Brasil: uma análise por faixa etária e região. Rev. Bras. Saúde Mater. Infant., 10(1), s83-s91. https://doi.org/10.1590/S1519-38292010000500008

Murray, C. J., Laakso, T., Shibuya, K, Hill, K., \& Lopez, A. D. (2007). Can we achieve Millennium Development Goal 4 ? New analysis of country trends and forecasts of under-5 mortality to 2015. Lancet, 370, 1040-54. https://doi.org/10.1016/S0140-6736(07)61478-0

Oyerinde, K. (2013). Can antenatal care result in significant maternal mortality reduction in developing countries? $J$ Community Med Health Educ., 3, 116. https://doi.org/10.4172/2161-0711.1000e116

Ramos, V. (2009). A consulta em 7 passos. Execução e análise crítica de consultas em Medicina Geral e Familiar. Revista Portuguesa de Medicina Geral e Familiar, 25(2), 208-20. https://doi.org/10.32385/rpmgf.v25i2.10609

Santos, L. A., Oliveira, E. S. B. E., Caldeira, A. P., \& Souza, A. A. M., et al. (2017). A percepção de médicos da estratégia saúde da família sobre as Internações por condições sensíveis à atenção primária. Rev. Unimontes Científica, 19(2), $2-12$.

Silva, L. A. (2011). Avaliação do grau de implantação da Estratégia Saúde da Família em municípios de pequeno porte. State University of Bahia. Theses.

Teixeira, C., \& Solla, J. P. (2006). Modelo de atenção à saúde: Promoção, Vigilância e Saúde da Família. Editora da Universidade Federal da Bahia. https://doi.org/10.7476/9788523209209

Tomasi, E., Fernandes, P. A. A., Fischer, T., Siqueira, F. C. V., Silveira, D. S., \& Thumé, E., et al. (2017). Qualidade da atenção pré-natal na rede básica de saúde do Brasil: indicadores e desigualdades sociais. Cad. Saúde Púb., 33(3), e00195815. https://doi.org/10.1590/0102-311x00195815

Vasconcellos, S. M. de, Bosi, M. L. M., \& Pontes, R. J. S. (2008). Avaliação e monitoramento da atenção básica no estado do Ceará, Brasil: explorando concepções e experiências no nível central. Cad. Saúde Pública, 24(12), 2891-2900. https://doi.org/10.1590/S0102-311X2008001200018

Viegas, A. P. B., Carmo, R. F., \& Luz, Z. M. P. da. (2015). Fatores que influenciam o acesso aos serviços de saúde na visão de profissionais e usuários de uma unidade básica de referência. Saúde Soc, 24(1),100-112. https://doi.org/10.1590/S0104-12902015000100008

\section{Copyrights}

Copyright for this article is retained by the author(s), with first publication rights granted to the journal.

This is an open-access article distributed under the terms and conditions of the Creative Commons Attribution license which permits unrestricted use, distribution, and reproduction in any medium, provided the original work is properly cited. 